\title{
Consumptive water use to feed humanity - curing a blind spot
}

\author{
M. Falkenmark ${ }^{1}$ and M. Lannerstad ${ }^{2}$ \\ ${ }^{1}$ Stockholm International Water Institute, Sweden \\ ${ }^{2}$ Department of Water and Environmental Studies, Linköping University, Sweden
}

Received: 15 November 2004 - Published in Hydrology and Earth System Sciences Discussions: 23 November 2004 Revised: 28 January 2005 - Accepted: 2 May 2005 - Published: 9 June 2005

\begin{abstract}
Since in large parts of the world it is getting difficult to meet growing water demands by mobilising more water, the discourse has turned its focus to demand management, governance and the necessary concern for aquatic ecosystems by reserving an "environmental flow" in the river. The latter calls for attention to river depletion which may be expected in response to changes in consumptive water use by both natural and anthropogenic systems. Basically, consumptive use has three faces: runoff generation influenced by land cover changes; consumptive use of water withdrawn; and evaporation from water systems (reservoirs, canals, river based cooling). After demonstrating the vulnerability to changes in consumptive use under savanna region conditions - representative of many poverty and hunger prone developing countries subject to attention in the Millennium Development Goal activities - the paper exemplifies; 1) changes in runoff generation in response to regional scale land cover changes; 2) consumptive use in large scale irrigation systems. It goes on to analyse the implications of seeing food as a human right by estimating the additional consumptive use requirements to produce food for the next two generations. Attention is paid to remaining degrees of freedom in terms of uncommitted water beyond an environmental flow reserve and to potential food trade consequences (so-called virtual water). The paper concludes that a human-right-to-food principle will have major consequences in terms of altered consumptive water use. It will therefore be essential for humanity to address river depletion to avoid loss of resilience of the life support system. This will demand a deep-going cooperation between hydrology, ecology and water governance.
\end{abstract}

\section{Introduction}

Water scarcity has been a core interest of the senior author since the early 1970's, and has in the late 1990's been gathering increasing international interest. For a long time, the

Correspondence to: M. Falkenmark

(malin.falkenmark@siwi.org) international debate had its focus on use-to-availability ratio relating to a more or less finite resource. Today, however, different circumstances call for interest on water scarcity as seen from the perspective of the outcome of increasing river depletion. There is for instance repeated reference in literature to the world's decreasing water resources and that "less and less water is available for human consumption" (Ambio, 2004). This is a statement that is however inconsistent with the general understanding that the amount of water circulating in the water cycle remains the same.

What is it then that gives the impression that water is getting scarcer? This could be just an indication of increasing water pollution. If it however refers literally to the amount of water, it may signify what we may call "river depletion", also referred to as neo-arheism (Meybeck, 2003), which has been described for a whole set of rivers; Yellow River, Indus, Colorado, Nile, Aral Sea tributaries, Indus, Ganges, MurrayDarling, Jordan, Lake Chad tributaries, Huai, Rio Grande, Chao Phraya rivers etc. (Lannerstad, 2002). There are already signs that this depletion may generate societal efforts to reduce the water use by putting a "cap" on further water withdrawals for irrigation (MDBC, 2003).

Such river depletion is also focused in the results of the scoping phase of the global UNEP-project GIWA (Ambio, 2004). The analysis of key causes of environmental problems in the 66 coastal seas, studied in that project, concludes that freshwater shortage is a dominating cause of the environmental problems experienced in at least 19 of the 66 coastal seas. This supports the need to put focus on freshwater shortage, especially flow modification and consumptive water use in irrigation.

Another scarcity related concern is the new concern for the environmental effects of over-appropriation of streamflow. While the environmental community has recently developed criteria for minimum flow for protection of aquatic ecosystems (Dyson et al., 2003), a world map presented by IWMI, IUCN, WRI and University of Kassel (Smakthin et al., 2004) suggests that the environmental flow needs have already been overcommitted in a broad belt across the continents from

(C) 2005 Author(s). This work is licensed under a Creative Commons License. 


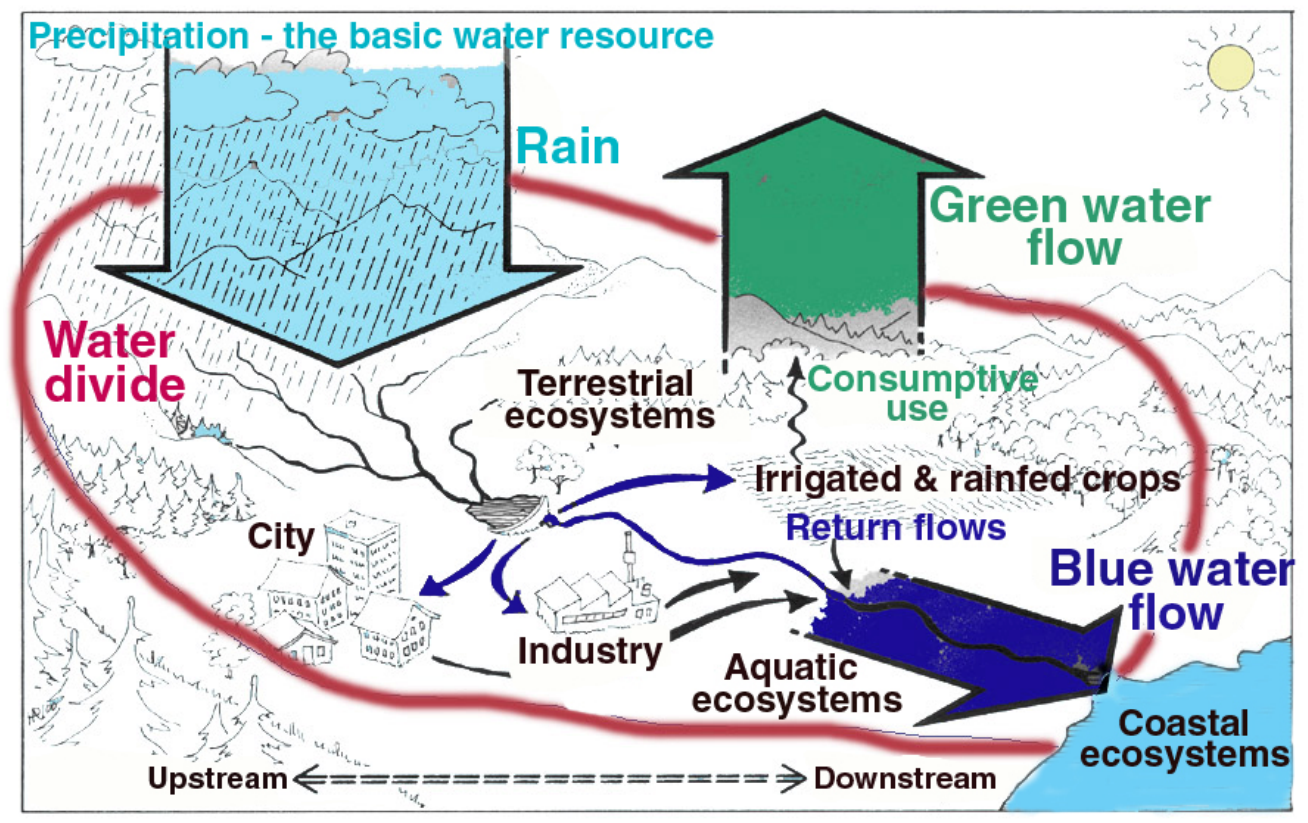

Fig. 1. In a drainage basin perspective, the precipitation over the area represents the proper water resource, part of which is consumed in plant production and evaporation from moist surfaces (green water flow) while the surplus goes to recharge aquifers and rivers (blue water flow) available for societal use and aquatic and coastal ecosystems.

Mexico in the west to N China in the east. Evidently, decreasing or non-existent river flow will also generate more or less serious societal conflicts in terms of both a spatial dimension, i.e. upstream - downstream conflicts of interest, and sector conflicts in terms of urban - rural competition, for instance between farmers and industry, or farmers and cities.

Moreover, while the main water debate has its focus on demand management, i.e. how to bring down demand by limiting/avoiding "losses" through overuse, leakages etc., most of the losses addressed are losses only from an economic perspective: leakages that return to the water system. The crucial issue behind river depletion is NOT losses/leakages but changes in "consumptive or depletive water use", i.e. evaporation during use with a vapour flow leaving the basin not available for reuse (until re-precipitated elsewhere through moisture recycling) (Molden et al., 2001; Kendy et al., 2003).

This paper has its focus on such consumptive/depletive water use, its relation to land cover change and socioeconomic development, implications of feeding a growing humanity and environmental and ecological consequences of changes identified.

\section{Consumptive water use}

\subsection{The concept}

Conventional statistics of water use offers data on water withdrawals for municipal, industrial and agricultural purposes.
Since many of the water uses to which the withdrawn water is being put are through-flow based uses where the water after use returns to the water system, it is basically only the consumptive use component or "evapotranspiration during use" that is relevant from the perspective of impact on downstream users and aquatic and coastal ecosystems. The return flow represents a quantity that can principally be reused over and over again in the basin, unless it is drained directly to the sea or to e.g. a salt sink for evaporation.

While evapotranspiration has conventionally been discussed as part of hydrological analyses in water balance studies, the concept blue as opposed to green water flow was introduced at a FAO seminar in 1993 in order to generate more management oriented interest to the consumptive use component of water use (Falkenmark, 1995). An overarching catchment approach allows a visual overview of the two main water outflows from the basin (Fig. 1). On a basin level, the green water flow component includes besides consumptive use by terrestrial and agricultural ecosystems also evaporation from wet surfaces and free water surfaces in wetlands, lakes and reservoirs.

Often the renewable groundwater is looked upon as a separate source as compared to renewable river flow. It is however elementary that, in a catchment approach, renewable groundwater is generally part of the hydrological cycle in the basin. It feeds the dry season base flow in local rivers; and groundwater fed wetlands depend upon the natural outflow from aquifers. 


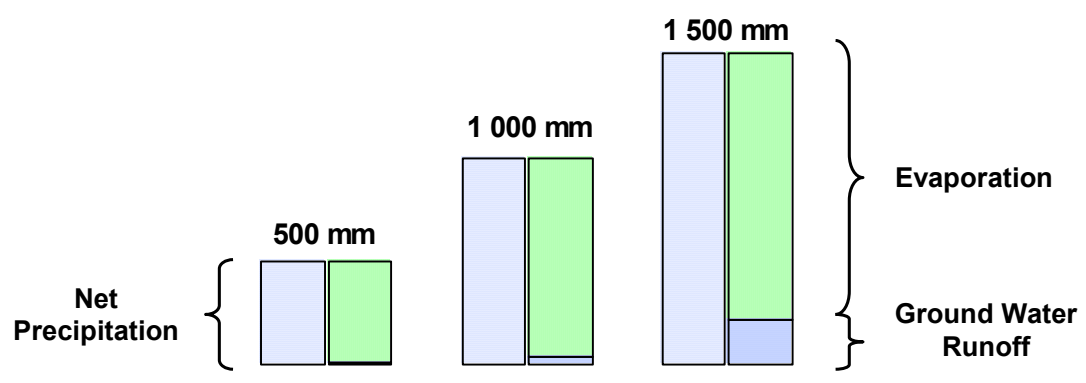

(a)

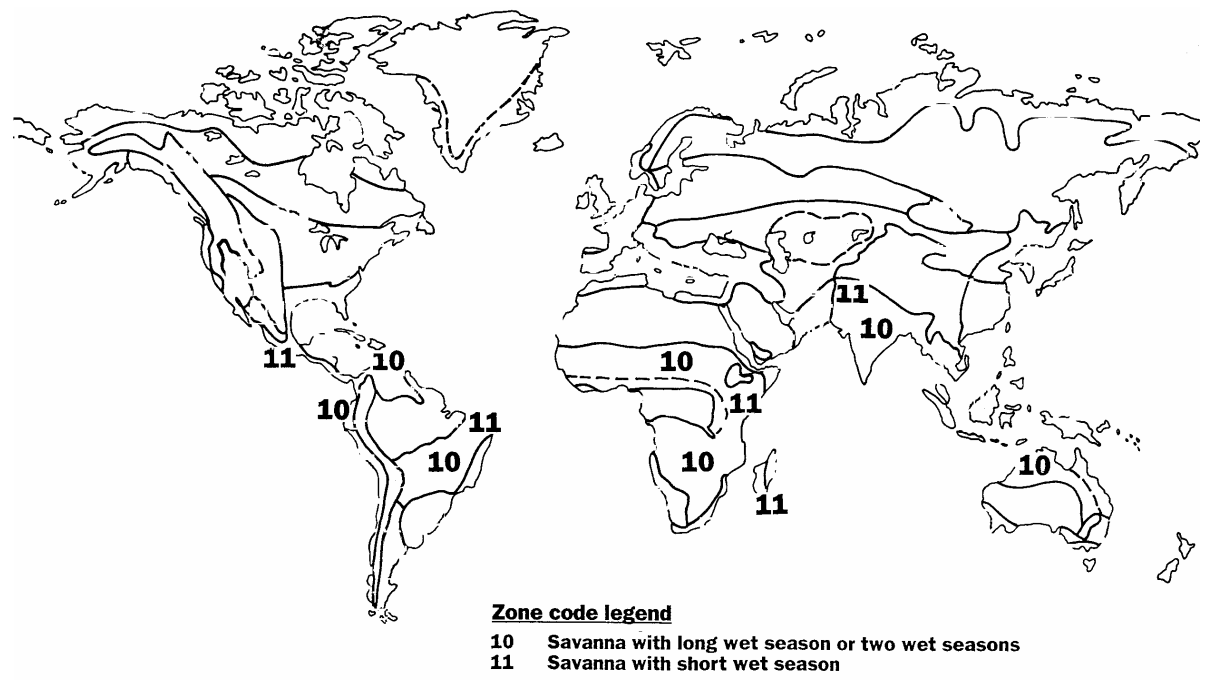

(b)

Fig. 2. (a) The blue/green rainfall partitioning in the semiarid zones for different amounts of net annually infiltrated rainfall (modified from L'vovich, 1979, p. 198). (b) A particularly vulnerable zone in terms of future river depletion is the savanna zone (regions 10 and 11 on the map of the main biomes of the world) (modified from Falkenmark and Rockström, 2004, p. 87).

\subsection{Vapour flow from different surfaces}

There is for some reason a fundamental difference in approach to water use by terrestrial ecosystems within conventional ecology as opposed to hydrology. Thus, the Millennium Ecosystem Assessment sees terrestrial ecosystems as water-provisioning rather than water-consumptive, which is as they come out from a hydrological aspect. Calder (2004) has drawn attention to the misleading misunderstanding that forests produce runoff. It is interesting to note for example that both Indian National Water Policy and Indian NGOs advocate and work for more trees to increase blue water flow, while the South Africans are taking the opposite approach, defining forest plantations as streamflow impacting activity for which the forest companies will have to pay for the additional water literally consumed.

Returning now to the blue/green conceptual model of the water leaving a catchment, the green water flow branch includes vapour flow from different surfaces: from irrigated fields, wetlands and evaporating water surfaces (blue water transformed into green), and from natural vegetation (intercepted and naturally infiltrated rainwater). Interesting from a river depletion perspective is evidently the degree to which increases in green water flow involve reduced runoff production and therefore reduced blue water flow.

\subsection{River flow vulnerability to change in the arid and semi- arid zone}

Changes in river flow may thus originate from different actions: increased or expanded irrigation, increased irrigation efficiency by reducing the surplus return flow, creation of large evaporating water surfaces (reservoirs), or altered land cover involving either increased evapotranspiration (e.g. forest plantations) or decreased evapotranspiration (e.g. deforestation).

Large attention was paid already in the 1960's to the green water flow by the Soviet scientist L'vovich (1979). He quantified the partitioning of precipitation for all the major biomes, based on data of precipitation and streamflow from all the continents, and analysed infiltration, actual evaporation and groundwater recharge in generic diagrams.

Typical for the steppe and savanna zone is the extremely limited groundwater recharge and baseflow production, 

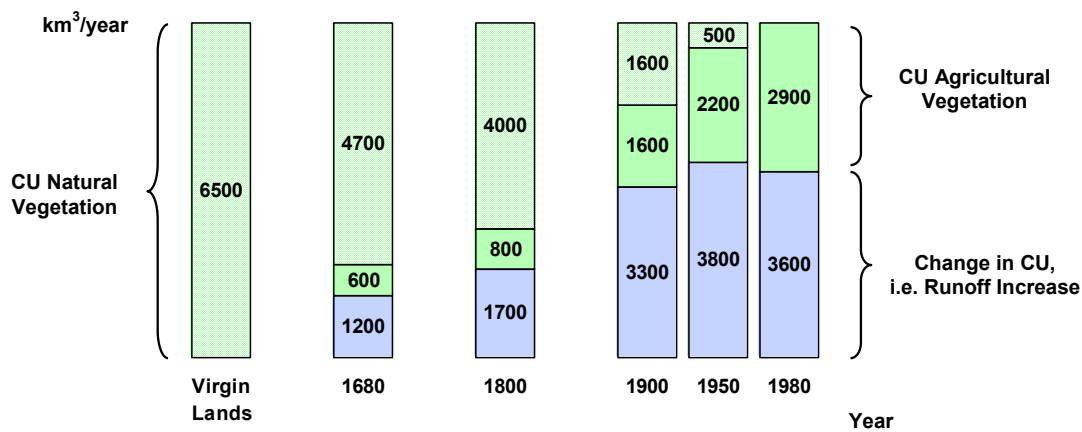

(a)

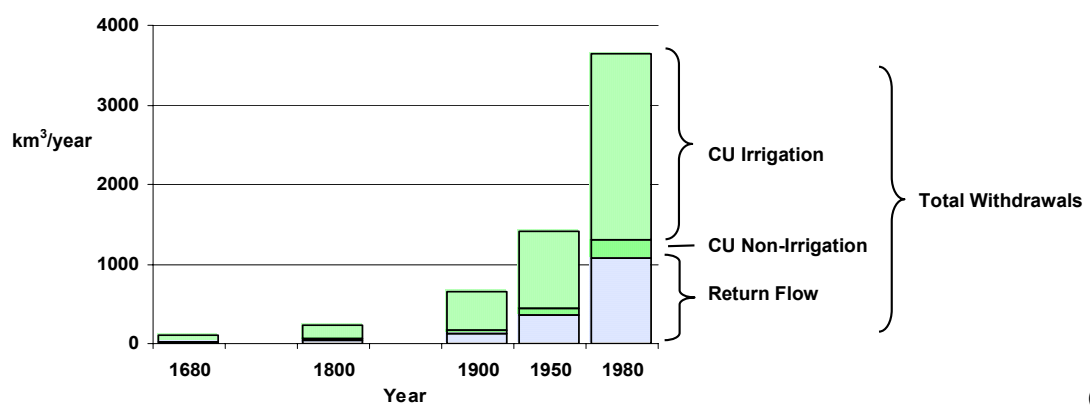

(b)

Fig. 3. (a) The columns show the historic change in $\mathrm{km}^{3} / \mathrm{year}$ of consumptive water use (CU) from total global area cultivated in 1980 compared to natural vegetation (virgin lands) with: $\mathrm{CU}$ from natural vegetation; $\mathrm{CU}$ from stepwise increased cultivation; and change in CU, i.e. blue water flow increase (modified from L'vovich and White, 1990, p. 247). (b) Total blue water withdrawals 1680-1980 and consumptive use component divided into irrigation and non-irrigation (modified from L'vovich and White, 1990, p. 242 and 245).

easily altered by land cover changes. Figure 2a shows that most of the infiltrated rainfall evaporates in the interval 500$1000 \mathrm{~mm}$ of rainfall and that on the whole, the groundwater recharge is minimal. Even moderate evaporation changes may cause blue water changes that are large on a relative scale.

L'vovich's diagrams can be used for studying possible changes in blue/green water partitioning and therefore in river flow generation linked to land cover changes. The high evaporative demand in the tropics plus the fact that it is in these areas where large land use changes are generated due to population growth and development efforts, suggests that the savanna zone is especially vulnerable. This zone includes many of the top and high priority countries now focused on in the Millennium Project with its efforts to meet the UN launched Millenium Development Goals (MDGs), many of which are directly water-related (poverty, hunger and unhealth alleviation) (Fig. 2b).

\section{Anthropogenic alterations of green/blue water flows}

\subsection{Global historical alterations}

Agriculture development to meet food needs of an increasing global human population has over time gradually converted large areas with natural vegetation to cultivated lands.
L'vovich and White (1990) made an estimate of how this land transformation resulted in "green-to-blue" water alterations (Fig. 3a). A decrease in consumptive use, i.e. increased blue water formation, culminated around 1950 when the vegetation on ploughed land consumed around $3800 \mathrm{~km}^{3} / \mathrm{yr}$ less than virgin vegetation. After that time consumptive use increased again, in response to changes in agro-technical methods, and was estimated to $2900 \mathrm{~km}^{3} / \mathrm{yr}$ in 1980 . A recent study of large scale redistribution of global water vapour flows by Gordon et al. (2004) supports this assessment by estimating global reduction of consumptive use due to deforestation to $3000 \mathrm{~km}^{3} / \mathrm{yr}^{1}$

In contrast consumptive water use of water withdrawn from rivers and aquifers represents "blue-to-green" alterations. L'vovich and White (1990) analysed global blue water withdrawals of surface and groundwater resources for the last three centuries. As can be seen in Fig. $3 \mathrm{~b}$ there has been a dramatic increase during the 20th century, the main part during the green revolution after WW II. Out of in total $2570 \mathrm{~km}^{3} / \mathrm{yr}$ consumptive water use from withdrawals in 1980, irrigated agriculture stands for more than $90 \%$, $2340 \mathrm{~km}^{3} / \mathrm{yr}$.

\footnotetext{
${ }^{1}$ As flow unit we have chosen the most commonly used unit in literature, $\mathrm{km}^{3} / \mathrm{yr}$. This unit is easier for readers to internalise and relate to, compared to the scientifically more correct SI unit $\mathrm{Gm}^{3} / \mathrm{yr}$.)
} 


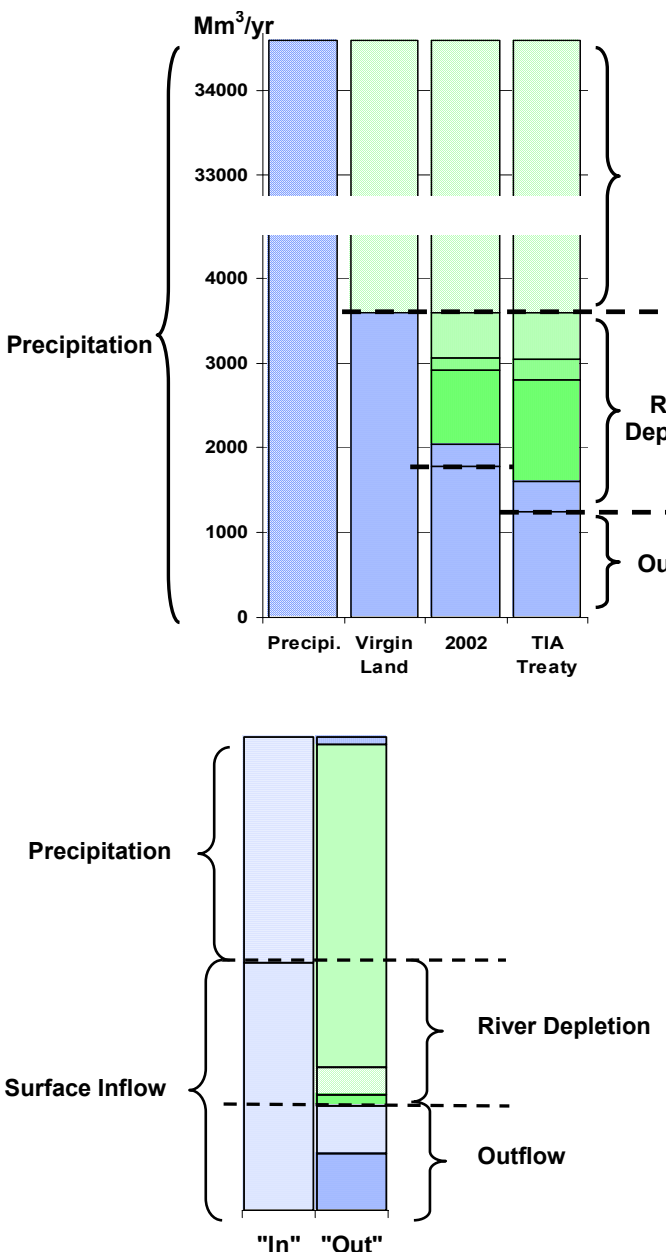

$\square$ CU Natural Vegetation

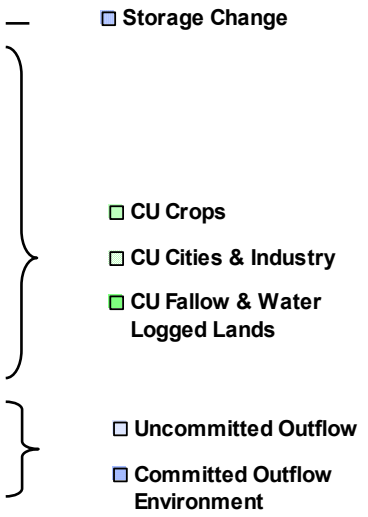

(b)

Fig. 4. (a) Human generated streamflow reduction in Incomati River Basin, Southern Africa. Blue green rainfall partitioning with virgin land use; by year 2002; and according to future implementation of the Triparty Interim Agreement. Three different types of water impacting activities are distinguished: entirely rainfed exotic tree plantations transpire more soil moisture than natural vegetation and thus decrease runoff formation; consumptive use of withdrawn quantities in domestic, municipal, industrial and agriculture sectors; and out of basin transfers (data from Van der Zaag and Carmo Vaz, 2003). (b) Water balance for the Bhakra irrigation scheme, NW India, 1995/1996. The command area is $1.5 \mathrm{Mha}$ and height of the staples "In" and "Out" are equivalent to $18000 \mathrm{Mm}^{3} / \mathrm{yr}$. Consumptive water use, mainly crops, evaporates the entire precipitation over the area and more than half of the surface inflow. Downstream water demands, here environmental concerns, are considered within "committed" outflows, accordingly "uncommitted outflows" is a resource still to be used and evaporated within the irrigation project (data Molden et al., 2001).

Consumptive water use from man-made freshwater storage is another "blue-to-green" alteration. Reservoirs for irrigation, hydropower etc. today have an estimated total volume of around $6000 \mathrm{~km}^{3}$ and cover an area of more than $500000 \mathrm{~km}^{2}$. Global reservoir consumptive use is estimated to around $200 \mathrm{~km}^{3} / \mathrm{yr}$ (L'vovich and White, 1990; Shiklomanov, 2000). In arid regions reservoirs can make a considerable contribution to surface water evaporation. Annual consumptive use from Lake Nasser/Nubia behind High Aswan Dam is estimated to as much as $11 \%$ of the lake volume (L'vovich and White, 1990). As the dam can store two year's inflow (Postel, 1999, p. 54) more than $20 \%$ of the yearly inflow might be lost to evaporation every year.

\subsection{Three basin illustrations of blue/green interactions}

An estimate of regional green-to-blue transformations was made by Gordon et al. (2003) for the Australian continent. During the last 200 years European settlers have made extensive clearance of perennial deep rooted forest vegetation. The estimated reduction of consumptive water use is almost as large as the present annual natural blue water flow from the continent. In Murray-Darling Basin 12 to 20 billion trees were replaced by short rooted grasses and seasonal crops. This vegetation change resulted in amplified blue water formation, with rising groundwater levels and increased river flow. The past 100 years a parallel 
development of construction of river regulatory and water storage structures have enabled large scale diversions, today mounting over $11000 \mathrm{Mm}^{3}$. Through increased consumptive use, yearly outflow to the sea today has thus decreased from an average of $12300 \mathrm{Mm}^{3}$ to $4900 \mathrm{Mm}^{3}$ (MDBC, 2004).

Another illustrative case is offered by the changes in the Incomati river basin in Southern Africa (Van der Zaag and Carmo Vaz, 2003) (Fig. 4a), where the net virgin runoff $\left(3587 \mathrm{Mm}^{3} / \mathrm{yr}\right)$ has been reduced step by step by altogether $1800 \mathrm{Mm}^{3} / \mathrm{yr}$ till 2002 , and can be predicted to decrease by another $500 \mathrm{Mm}^{3} / \mathrm{yr}$ in line with the recent riparian Triparty Interim Agreement. Interesting to notice is the increased consumptive water use by exotic tree plantations, almost $550 \mathrm{Mm}^{3} / \mathrm{yr}$. These plantations are entirely rainfed and are another example of how land use changes can alter natural hydrology and reduce blue water formation. The final outcome of increased green water flow from both rainfed and irrigated areas will in other words be a reduction of primary blue water flow by $2300 \mathrm{Mm}^{3} / \mathrm{yr}$, leaving only $35 \%$ of the original streamflow for freshwater and downstream coastal ecosystems.

Another carefully researched illustration of blue-to-green redirection is offered by IWMI's water accounting analysis of the water balance of the Bhakra sub-basin irrigation project of 1.5 Mha in northwest India, visualising the consumptive use and river depletion (Molden et al., 2001). The entire precipitation falling in the area and around 55\% of the blue water inflow to this huge irrigation project was transformed into green water flow, above all by crops (Fig. 4b).

\subsection{Modern world signals in terms of increasing blue water scarcity}

As a consequence of increase in consumptive blue water use (Fig. 3b), a disturbing trend of large scale river depletion and falling groundwater levels have become evident in the arid and semi arid zone (Postel, 1999; Plate 3 in Kijne et al., 2003). A whole set of hot spots have already developed in regions which are at the same time hunger prone, drought vulnerable and with increasing populations.

\subsubsection{River depletion}

River depletion is characterised by reduced river flow relative long time average; some rivers have changed from perennial to intermittent. The major reason is consumptive water use by irrigation (Lannerstad, 2002). As the trend is prevalent after 1950, Meybeck (2003) designated a river flow reduction of at least $50 \%$ as "neo-arheism", "new absence of flow". Considerably reduced river flow in many basins imperils societal development, increases the competition between upstream and downstream users and threatens water dependent terrestrial, freshwater and coastal ecosystems.

The most evident example is the Aral Sea where large scale irrigation along the tributaries Amu Darya and Syr
Darya has reduced this inland water body, once the fourth largest, by half it's area and three quarters of it's volume. Disappearing delta areas cause the extinction of habitats and endemic species. A collapsed fishing industry and serious human health problems are some of the societal effects (Glantz, 1998).

Along the Colorado River successful reservoir construction during the last century today enable a total storage of almost five times average yearly flow. The Colorado River supports irrigation of 800000 ha and supplies drinking water to 25 million people, 16 million "out of basin" in southern California. Since 1960 there have not been almost any discharges to the Californian Gulf and the last measuring station, El Meritimo in Mexico, closed down in 1968 (Postel, 1995).

The naturally perennial Indus River today irrigates more than 14 million ha in Pakistan. After completion of a number of large scale reservoirs the days of zero outflows to the Arabian Sea during the last 25 years have reached an average of 81 days during dry season and 26 days during wet season. On average only $21 \%$ of historical dry season flow now reach the delta and coastal ecosystems (Asiancs, 2000).

In 1972 the lower course of the Yellow River dried up for the first time in history. In 1997 the dry-up lasted for 226 days and reached $700 \mathrm{~km}$ up-stream. Reduced dilution of industrial effluents threatens human health of millions in the river valley. Periods of little or no flow leave the fertile delta plains without irrigation water and cause extensive siltation of the main canal, posing a threat to river dikes during flooding (Ren and Walker, 1998).

In the Rio Grande/Rio Bravo Basin, New Mexico, Texas and Mexico are competing for scarce water resources. In 2001 the river for the first time failed to reach the Gulf of Mexico (Economist, 2001). Economic expansion with production of cash-crops for the U.S. market, following the North America Free Trade Treaty, together with several years of drought forced Mexico to exceed its river flow share and in 2000 thus owed the U.S. $1.2 \mathrm{~km}^{3}$. The population in the area is projected to double by 2020 (Economist, 2000).

\subsubsection{Groundwater overdraft}

Since 1950 a number of concurrent development steps as geological knowledge, well drilling, pump technology and rural electricity infrastructure have opened up for extensive groundwater exploitation (Foster and Chilton, 2003). Rosegrant et al. (2002, p. 157) estimate total groundwater use in 1995 to more than $800 \mathrm{~km}^{3}$, out of which as much as $200 \mathrm{~km}^{3}$ is overdraft of non-recharged groundwater contributing to long-term groundwater depletion (Postel, 1999, p. 80). Postel suggests that this equals around 180 tons of grain or about $10 \%$ of global harvest. The major groundwater depleting nations (mid $1990 \mathrm{~s}$ ) are $104 \mathrm{~km}^{3} / \mathrm{yr}$, China $30 \mathrm{~km}^{3} / \mathrm{yr}$ and US $14 \mathrm{~km}^{3} / \mathrm{yr}$ (Postel, 1999, p. 80). 
The former IWMI Director General David Seckler assessed as much as a quarter of India's harvest to rely upon groundwater overdraft. Gujarat is one of several groundwater depleting states in India. In North Gujarat 30 years ago bullock bailers could lift water from 10-15 $\mathrm{m}$ depth. Today tube wells with $35-75 \mathrm{hp}$ pumps in some areas force groundwater, often fluoride contaminated, from more than $400 \mathrm{~m}$ to the surface. In the Gujarat Saurashtra coastal area farmers during 1960's and 1970's through extensive groundwater pumping experienced a tube well economy boom. Now sea water intrusion in these depleted coastal aquifers reaches $7 \mathrm{~km}$ inland and socioecological collapse is the reality for many villages (Shah et al., 2000). Already in 1976 UNDP estimated that groundwater abstractions in Gujarat had to be reduced by $25 \%$ to reach sustainable levels (Moench et al., 2003).

The most well known groundwater depletion example in the U.S. is the Ogallala aquifer below the U.S. Great Plains. It covers an area of $453000 \mathrm{~km}^{2}$ and waters one fifth of U.S. irrigated land. Yearly groundwater overdraft is estimated to $12 \mathrm{~km}^{3}$ and altogether so far to more than $325 \mathrm{~km}^{3}$. In 1978 the Ogallala groundwater irrigated a peak area of 5.2 million hectares. Falling water tables with increased pumping costs in combination with low crop prices had reduced the area by $20 \%$ a decade later and by 2020 only $60 \%$ of the record area is projected to remain under irrigation (Postel, 1999, p. 77).

North China Plain stretches over $320000 \mathrm{~km}^{2}$ and has a population of over 200 million. The area embraces $64 \%$ of national farmlands with half of China's wheat production and one third of the maize harvest (Kendy et al., 2002; Shah et al., 2000). The area is facing serious groundwater overexploitation problems, with the groundwater table under Beijing fallen $5 \mathrm{~m}$ since 1965, $2.5 \mathrm{~m}$ in 1999 (Moench et al., 2003). The Hai basin suffers a yearly groundwater depletion of almost $9 \mathrm{~km}^{3}$ (Foster and Chilton, 2003). Moench et al. (2003) cite a water strategy report from 2001 for North China by the Chinese Ministry of Water Resources. The report especially focuses on the Hai, Huai and Yellow (3-H) Rivers: "The serious and largely irreversible falling groundwater levels throughout the North China Plains demands ... a program ...to reduce groundwater use to sustainable levels ... consequences of not doing it will have major long term implications, such as effectively destroying the groundwater dependent agriculture base, massive subsidence and sea water intrusion, virtual elimination of groundwater as water resource for many cities and countless households and the loss of "insurance" water for future generations".

\section{Meeting expanding green water needs}

We have seen above that human activities on land tend to on the one hand influence the runoff generation and the blue water flow, and on the other introduce a "blue-to-green" redirection through irrigation of agricultural land. What will then be the effects of feeding a growing humanity? And how will this influence future streamflow?

The largest future challenge is of course the global hunger alleviation efforts in line with the solemnly declared Millennium Development Goals launched by the United Nations Millennium Summit in September 2000. Considering the continued growth of the human population and changed preferences as income rises and urbanisation expands, we can foresee that larger and larger amounts of water will have to be appropriated as consumptive water use for growing that food. We may even have to accept that this will have effects in terms of even larger river depletion.

But beyond the increased consumptive use linked to producing the food for a growing humanity, there is the need to rehabilitate the problems caused by the already manifested river depletion beyond the requirements of healthy aquatic ecosystems and by groundwater overdraft. What can be said about these necessary future changes?

\subsection{Additional consumptive use to feed the world}

The amounts of green water flow appropriated per capita for current food production have been shown by Gleick (2000), based on diets in different regions, to vary by a factor 3 between around $600 \mathrm{~m}^{3} \mathrm{p}^{-1} \mathrm{yr}^{-1}$ in the widely undernourished Sub-Saharan Africa and $1800 \mathrm{~m}^{3} \mathrm{p}^{-1} \mathrm{yr}^{-1}$ in North America with its rich meat diet. In order to estimate the green water needs for feeding the entire world population, the approximate green water requirements for an "acceptable nutritional diet" have to be known. Rockström (2003) arrived at $1300 \mathrm{~m}^{3} \mathrm{p}^{-1} \mathrm{yr}^{-1}$ assuming $3000 \mathrm{kcal} \mathrm{p}^{-1} \mathrm{~d}^{-1}$ (FAO prediction as global average by 2030), and $20 \%$ animal protein. He found this to be almost a generic value irrespective of climate, the reason being that regional differences in evaporative demand are being compensated by differences in water use efficiency between $\mathrm{C} 3$ and $\mathrm{C} 4$ plants. $^{2}$

Applying this on the one hand to the predicted population growth till 2025 and 2050 respectively, and on the other for raising the diet in today's developing countries to $3000 \mathrm{kcal} \mathrm{p}^{-1} \mathrm{yr}^{-1}$, Rockström arrived at an additional green water requirement of $3800 \mathrm{~km}^{3} / \mathrm{yr}$ one generation from now (by year 2025), growing to an additional $5600 \mathrm{~km}^{3} / \mathrm{yr}$ two generations from now (by year 2050) (Rockström, 2003). Noting that the total green water flows from ALL blue water withdrawals in 1995 was $2100 \mathrm{~km}^{3} / \mathrm{yr}$ (Shiklomanov, 2000), present water productivity indicates that additionally almost

\footnotetext{
${ }^{2} \mathrm{C} 3$ and $\mathrm{C} 4$ are two different metabolic pathways associated with the photosynthesis fixation of carbon dioxide. C3 plants use the $\mathrm{C} 3$ photosynthetic carbon reduction (PCR) cycle, while $\mathrm{C} 4$ plants also use the $\mathrm{C} 4$ photosynthetic carbon assimilation (PCA) cycle. In drier and hotter climates this enables the $\mathrm{C} 4$ plants to be more water efficient compared to $\mathrm{C} 3$ plants and decreases the water vapour loss through the stomata when assimilating carbon dioxide. Examples of $\mathrm{C} 4$ plants are: maize, sugarcane, sorghum and several other grasses (Taiz and Zeiger, 1991).
} 
twice this quantity will have to be appropriated in the next half century for alleviating hunger.

The degrees of freedom in terms of water available for meeting these water requirements are however limited since experience from the past suggests that increased consumptive use in a river basin will reduce streamflow, impacting both downstream water users and their livelihoods and aquatic ecosystems. A minimum flow, i.e. "environmental flow", has to remain in the river for protection of aquatic ecosystems and downstream coastal ecosystems. This minimum flow has been determined by different methods (Tharme, 2003). The simplest thumb rule estimates this amount to some $30 \%$ of the natural streamflow in the tropics (where aquatic life is already adapted to a dry season), and some $50 \%$ in the temperate zone (with precipitation all year round) (Smakthin et al., 2004).

\subsection{Options and global orders of magnitude}

The question is therefore what the options are for meeting the additional green water need for food production. There are principally three options: 1) reduced non-productive green water losses, i.e. increased agricultural productivity per drop of water evaporated (both irrigated and rainfed cropping systems); 2) expanded irrigation; 3) horisontal expansion of rainfed agriculture. Let us try to quantify at least the orders of magnitude of these respective options.

As regards the first option, the basic question is how much of the current green water flow that can be redirected through "vapour shift" from non-productive evaporation (sometimes also called "white water") into productive transpiration (Rockström, 2003). According to Shiklomanov (2000), out of the $2500 \mathrm{~km}^{3} / \mathrm{yr}$ withdrawn globally in 1995 for agriculture, $1750 \mathrm{~km}^{3} / \mathrm{yr}$ represents consumptive use. Irrigated agriculture has however generally been quite wasteful in water use. Not only are the blue water losses considerable but part of the green water flow is non-productive. If we - as a very coarse first approximation - assume that as a global average only say $40 \%$ of the water withdrawn reaches the plants, then $1000 \mathrm{~km}^{3} / \mathrm{yr}$ represents the productive component of the consumptive use, while $1750-1000$ or $750 \mathrm{~km}^{3} / \mathrm{yr}$ represents non-productive component that may be principally "regainable" by increased water productivity in terms of production per drop evapotranspired. Also rainfed agriculture involves large non-productive losses. Out of an assessed $5000 \mathrm{~km}^{3} / \mathrm{yr}$ of green water use (Rockström et al., 1999), a careful analysis of what might be achievable by 2050 from increased productivity in rainfed crop production suggests that $1500 \mathrm{~km}^{3} / \mathrm{yr}$ might be "regainable", i.e. reduce future consumptive use demands by $1500 \mathrm{~km}^{3} / \mathrm{yr}$ (Falkenmark and Rockström, 2004). We therefore find - being as optimistic as possible - that out of the required $3800 \mathrm{~km}^{3} / \mathrm{yr}$ by 2025 (5600 by year 2050), a maximum of $750+1500$ or $2250 \mathrm{~km}^{3} / \mathrm{yr}$ might possibly be regained from today's green water flow by productivity increase, i.e. a maximised "crop per evaporated drop" policy.

This leaves a global minimum of 3800-2250 or $1550 \mathrm{~km}^{3} / \mathrm{yr}$ by year 2025 (3350 by 2050) to be covered by either increased irrigation or expansion of rainfed agriculture into other areas. According to optimistic assessments based upon FAO projections (Falkenmark and Rockström, 2004, p. 61) we might only expect an irrigation expansion of some $600 \mathrm{~km}^{3} / \mathrm{yr}-$ this is the part of the green water that will have evident blue water consequences. Even these very optimistic "guesstimates" leaves at least $1000 \mathrm{~km}^{3} / \mathrm{yr}$ by 2025 (2800 by 2050) to be covered by horizontal expansion into grasslands and forests.

\subsection{The blue water perspective: conflict with environmen-} tal flow

What these approximations suggest is that feeding humanity involves the risk that globally river depletion rises from current $2100 \mathrm{~km}^{3} / \mathrm{yr}$ (Shiklomanov's estimate of consumptive blue water use) to $2700 \mathrm{~km}^{3} / \mathrm{yr}$ by a moderately expanding irrigation. (Whether irrigation is based on surface or renewable groundwater has limited relevance since consumptive groundwater use is equivalent to transforming blue low flow recharge to green water flow). Increased river depletion will aggravate both the societal water stressed situation and further hurt already degraded aquatic ecosystems.

The current over-appropriation of streamflow has been highlighted by Smakthin et al. (2003) who analysed streamflow in relation to minimum requirements for healthy aquatic ecosystems (30\% in dry climate regions). They showed that more than $70 \%$ of the flow is already being withdrawn in a broad belt from Mexico through North Africa, West Asia, Central Asia to North China. Considering the underlying data, which are withdrawal data that do not distinguish consumptive from non-consumptive water use, the map, however, fortunately exaggerates the impression of over-commitment.

Evidently, the basic river depletion conflict of interest is between more consumptive use for feeding humanity and more baseflow in the rivers for environmental flow protection. Figure 5 gives an idea of the situation by 1995 for a number of river basins in India, China, U.S., and for recent years for a couple of African basins. The vertical scale shows withdrawal-to-availability ratio, where maximum $70 \%$ is acceptable since the remaining $30 \%$ have to be left uncommitted for environmental flow requirements. The horizontal scale shows water crowding level.

\section{Degrees of freedom in terms of consumptive water use}

\subsection{Over-appropriated regions}

The diagram (Fig. 5) shows that in S and E Asia, the 70\% withdrawal level was surpassed in a whole set of large basins 


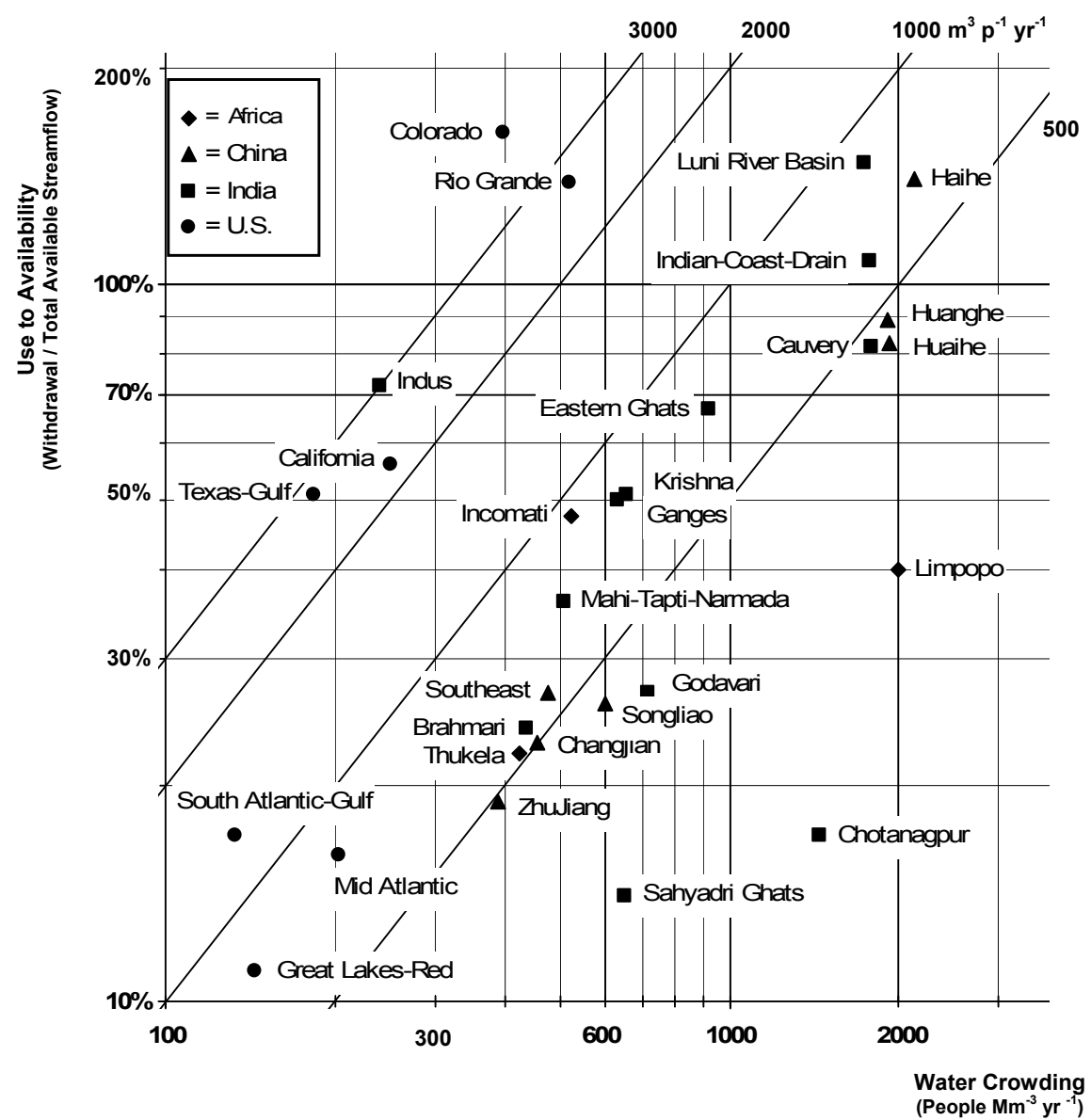

Fig. 5. Remaining degrees of freedom for increased consumptive use in a set of river basins. Diagram relates "withdrawal to availability ratio" in per cent (vertical axis) and "water crowding" in people per flow unit of 1 million $\mathrm{m}^{3} / \mathrm{yr}$ (horizontal scale). Diagonals show per-capita water withdrawals. Beyond $70 \%$ withdrawal level basins are closed and no degrees of freedom are left, due to needs of aquatic ecosystems. (Data: China, India and U.S., year 1995, data source IFPRI (2002). Africa, recent years, various data sources.).

already in 1995 indicating an over-appropriation beyond the needs of aquatic ecosystems.

- India: Indus and Cauvery rivers, with Indian-CoastalDrain and Luni river even surpassing $100 \%$ level and E Ghats rivers were very close to the $70 \%$ line.

- China: Huai and Yellow rivers surpassing 70\%, and Hai River already beyond $100 \%$.

In Subsaharan Africa most farmers are however rainfed, and withdrawal levels therefore fairly low. Since many of the over-appropriated river basins are evidently located in the semiarid zone, proper attention has in other words to be paid to what the degrees of freedom really are.

Is humanity in terms of water for food approaching the carrying capacity of the planet? The conclusion this far is that future water needs to feed humanity on an acceptable nutritional level will be meeting severe conflicts of interest with environmental flow requirements due to the risk for additional river depletion from irrigation expansion in drought vulnerable agriculture.

\subsection{Food import as an alternative}

The diagram suggests that the already overcommitted basins in India and China will meet severe water scarcity problems in feeding their growing populations and altered food preferences. Where food self-sufficiency is not possible due to water constraints, import has to be considered a possibility. This alternative is sometimes referred to as virtual water flow, as the imported food represents a consumptive use of water resources in another country. Since access to safe water and adequate food have been defined as human rights in an International Covenant on Economic Social and Cultural Rights and can therefore be seen as "legal water entitlements" to everyone, the consumptive use linked to food production (with present water productivity $1300 \mathrm{~m}^{3} \mathrm{p}^{-1} \mathrm{yr}^{-1}$ ) has to be seen as unavoidable. 
What we may refer to as the future minimum virtual water trade can be estimated from the fact that the environmental flow reserve allows maximum $70 \%$ of the natural streamflow to be allocated to food production. Basins close to or beyond that level will have to import the surplus from better endowed regions. Some indications of the relation between food trade and blue water scarcity can be gathered from the studies of Yang et al. (2003), showing that, statistically, food import tends to increase with growing water crowding below a threshold of $1500 \mathrm{~m}^{3} \mathrm{p}^{-1} \mathrm{yr}^{-1}$ (Yang et al., 2003). This corresponds to 670 people per flow unit on the water crowding scale in Fig. 5.

Let us now assume that from the $1300 \mathrm{~m}^{3} \mathrm{p}^{-1} \mathrm{yr}^{-1}$, or for simplicity say $1000 \mathrm{~m}^{3} \mathrm{p}^{-1} \mathrm{yr}^{-1}$, half is met by infiltrated rainfall and that the remaining half has to be met by irrigation. This gives a blue water need of $500 \mathrm{~m}^{3} \mathrm{p}^{-1} \mathrm{yr}^{-1}$. Figure 5 shows that a vertical line through $670 \mathrm{p} /$ flow unit on the horizontal scale meets the $500 \mathrm{~m}^{3} \mathrm{p}^{-1} \mathrm{yr}^{-1}$ water use diagonal at the level $35 \%$ use-to-availability ratio on the vertical scale. This suggests that food import to a particular country may start far below availability a withdrawal level of $70 \%$. The 2025 population living in countries beyond a threshold level of $600 \mathrm{p} /$ flow unit has earlier been estimated at some 3 billion (Falkenmark, 1993). If, say, half of their food would have to be imported, this would correspond to some $500 \mathrm{Mton} / \mathrm{yr}$, implying an approximate doubling of the present inter-country food trade in only just beyond 20 years in line with the warning issued in the early 1990's by A. McCalla, former chairman of CGIAR.

\subsection{The example of China}

China accommodates one fifth of the world's population and is undergoing rapid economic growth, large scale urbanisation and has a yearly population increase of more than 9 million (UN, 2003). This rushed development will increase the demand for more and different food items. The progressively more prosperous Chinese are expected to "move up the food chain" and consume larger quantities of water consumptive items as fruits, vegetables and grain-fed livestock products as pork, poultry and eggs (Brown, 2004). At the same time, China is suffering from extensive blue water depletion in terms of both river depletion and severe groundwater overdraft. It is therefore an informative case to analyse when considering water scarcity in relation to food security and future global food trade (Rosegrant et al., 2002; Brown, 2003a, b, 2004; Bange, 2004).

Rosegrant et al. (2002) have estimated food and agricultural development for China from 1995 to 2025 in line with current food-water trends, a "business as usual scenario". According to this depiction total cereal demand in China will increase by more than $50 \%$ in that period, with a $15 \%$ increase of food cereals, and a $140 \%$ escalation in feed grains. The boost in feed cereal demands reflects the expected rise in meat demand, an increase representing 39\% of expected total world meat demand growth. Since Chinese grain production is not expected to keep pace with demand, Rosegrant et al. picture an annual import of around 40Mton grains by 2025.

Brown (2003a, b, 2004) points out that grain production in China from 1998 till 2003 plummeted by 70 Mton - a drop that exceeds Canada's entire grain harvest! Several factors contribute: decrease in grain harvested land, loss of irrigation water, shift to higher value crops, conversion of cropland to other use (e.g. urban) and farm labour deficiency due to migration to urban areas. China has so far covered production deficit by reduction of earlier huge grain reserves but will in the near future have to rely on food production outside its borders and need to import 30-50 Mton per year. This food trade demand will dramatically change food prices on the world market. As U.S. stands for around 50\% of world grain export Brown anticipates a "huge umbilical cord" with several grain loaded ships leaving U.S. for China every day.

But strong economic growth in China since numerous years has increased demands also for agriculture-produced raw materials such as cotton. Efforts are also ongoing to transform China's agriculture into a market-based system with allocation of scarce land and water resources based on highest value, prioritising cotton, soybeans and horticultural crops. Considerable trade changes are therefore emerging. Looking beyond 2004/2005 income rises and diets change in China will on one hand reduce rice consumption and again make China become a net rice exporter. Altered food preferences will on the other hand make China remain a major wheat importer and turn China into a significant maize importer, for meat production and industrial uses. Protein demand will increase globally and China will be the most important driver behind this development, projected to depend on imports for $70 \%$ of its soybean needs (Bange, 2004).

These trends have now turned China into a net-grain importer affecting world prices. Bange (2004) points out that grain stocks in China, and thus globally, have fallen dramatically the last years. To reduce imports recent China policy decisions therefore try to motivate farmers to switch back from cash-crops to staple food production. Whether successful or not is difficult to foresee. As pointed out by Bange: the "over-riding concern is the continuing problem of water scarcity that may constrain China's ability to expand crop production".

\subsection{Future outlook}

We have now seen that expected alterations in consumptive water use, mainly in agriculture, will be a crucial issue for both human and ecological security already in the near future. But also forest plantations, needed to replace fossil fuels by renewable energy to moderate climate change will be part of the overall water equation and be involving 


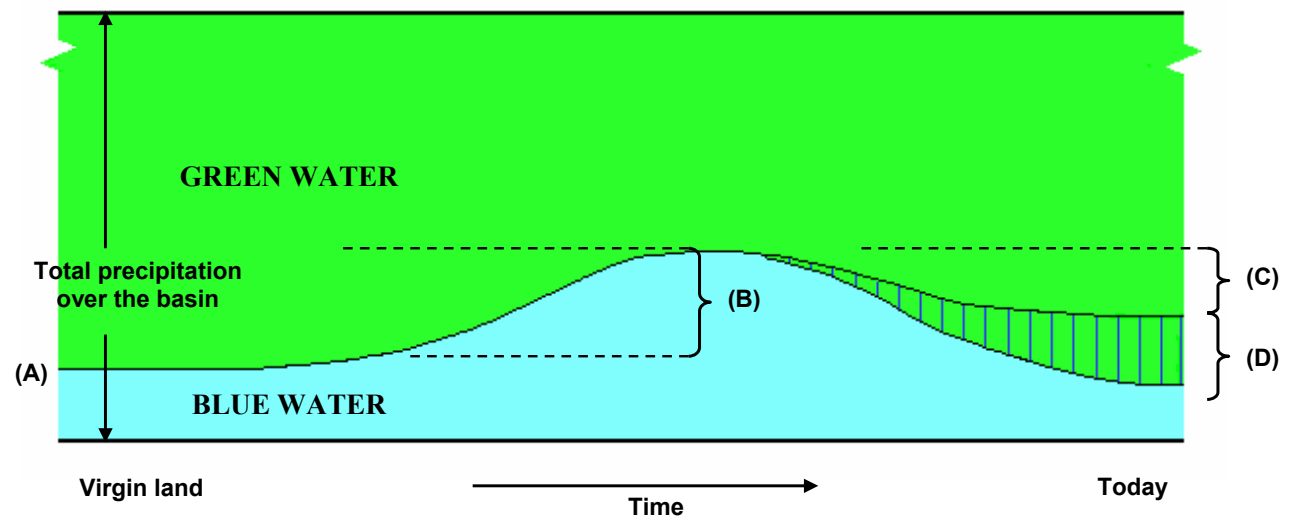

Fig. 6. Changes over time in water partitioning in a typical basin from un-disturbed to present. The height of the figure equals the yearly precipitation over the basin. The figure shows how this water quantity "leaves the basin" (see also Fig. 1) as a green or a blue water flow and how this partitioning changes over time. (A) Virgin land has evolutionary optimised vegetation, with large green water flow. (B) Forest clearance to gain pasture and crop lands, with less green water flow from seasonal and short rooted vegetation, increase blue water flow. Green-to-blue redirection. (C) Improved agricultural techniques and crop improvement increase green water flows again, with reduced runoff, blue water, formation. Streamflow reducing land use. (D) Consumptive water use, mainly for irrigation, from river flow and groundwater together with evaporation from reservoirs directly reduce river flow and increase the amount of precipitation input leaving the basin as a green water flow. Blue-to-green redirection (not to scale).

consumptive water use challenges of a similar order of magnitude as agricultural production, according to Berndes (2002).

Also climate may be causing alterations in consumptive water use. Such changes have not been taken into account in our study. Climate change effects are a question of time and scale: it appears to be difficult also for experts in this field to quantify and geographically locate changes in precipitation and evaporation. Most certainly climate change will influence global, regional and local hydrological cycles and the distribution of precipitation that follows increases and decreases in evapotranspiration. Some research indicates that the occurrence of extreme weather conditions is increasing. If so, this will increase the difficulties for successful agricultural production in many areas. Sub Saharan Africa is especially vulnerable in this respect since this area is already suffering from recurrent drought years and dry spells.

In this study we have not paid attention to regional effects of moisture recycling and the destiny of the evaporated water due to our focus on consumptive water needs. There are however studies on the effects of green flow alterations: from deforestation both on the Sahel region drought by Savenije (1996), and in terms of the savannisation of the Amazon basin (Oyama and Nobre, 2003).

Evidently, the direct link between green and blue water flows makes it essential to address the future from both a green and a blue water perspective in order to be able to highlight also the trade offs involved between environmental flow and river depletion risks.

\section{Conclusions and discussion}

\subsection{Changes in green water flow}

Increase of water scarcity in many catchments is often explained by decreased precipitation. The explanation in most basins is however NOT a reduced water input, but instead a significant increase in consumptive water use. In this paper we have analysed the consumptive water use as the key determinant affecting blue water flows, causing river depletion and groundwater overdraft.

Through a number of examples, at global and basin levels, different kinds of human alterations and their impacts of green and blue water partitioning have been presented in the text. According to a general trajectory seen in many semiarid basins initial agricultural development starts with clearance of natural vegetation to gain farming lands, resulting in a decrease in green water flows from the basin. Later, especially during last century, construction of reservoirs and irrigation infrastructures, with intensive blue water use, together with crop and agricultural technique improvements have increased consumptive use again. Figure 6 shows a schematic visualisation of general consequences over time in a river basin in terms of green-blue partitioning caused by vegetation alterations and water resource development. The figure has a blue water perspective with the aim to show how green water flow changes affect the outflow from the basin, and thus cause river depletion. In addition to analysing changes in blue versus green flows it is from a consumptive water use basin productivity perspective also important to notice that the relation between productive and non-productive green water flows change over time. As improvements in irrigation 
management and agricultural practices have resulted in a gradual "vapour shift" towards a higher relative part as productive transpiration, the basin productivity increase might be much higher than the actual total green water increase implies.

Blue water flows can thus be altered in three ways:

1) by vegetation changes, with increased or decreased evapotranspiration, altering runoff formation,

2) by consumptive use of renewable groundwater, reducing aquifer outflows to rivers and wetlands, or

3) by consumptive water use of river flow, through direct use, e.g. irrigation, and through indirect use as evaporation from storage surfaces.

The analysis shows the importance, when discussing water use, of properly distinguishing between the consumptive, evaporative, component of water use and the nonconsumptive component, returning to the system. The latter is traditionally often perceived as "losses", but principally constitutes a return flow that can be used again downstream. Moreover, the consumptive component also includes losses in terms of excessive non-productive vapour flow from farmlands (unnecessary evaporation).

\subsection{Future}

Most studies, e.g. FAO study 2015/2030 (FAO, 2003), of future food production involve a "projection" of foreseeable changes in food consumption and production, based upon plausible assumptions of irrigation and market development. Our study differs from these studies by being a "backcasting" estimate that aims at demonstrating the water implications of taking seriously the need to feed humanity on an acceptable nutritional level $\left(3000 \mathrm{kcal} \mathrm{p}^{-1} \mathrm{~d}^{-1}\right.$ as predicted by FAO as an average for developing countries by 2030 , out of which $20 \%$ animal protein).

In meeting future food needs large changes in green water flows can be foreseen. When taking a global perspective to reach proper nutrition in developing countries and of the 3 billion unborn further increases in global agricultural consumptive water use will be requested. Based upon present water productivity additional future consumptive water use equals almost twice the present consumptive water use from all withdrawals.

In the paper the order of magnitude for three options has been assessed; 1) better use of present consumptive water use (regaining non-productive green water losses by water productivity increase, i.e. "vapour shift"); 2) additional water for irrigation to be appropriated from renewable blue water resources; 3) horizontal expansion of rainfed agriculture into terrestrial biomes, presently not used for agriculture, such as grasslands and forests.

In water scarce areas food import will be a fourth option. A number of countries already to large degree rely on food imports, such as North Africa with half their grain use based upon imports, while other countries will most probably become import dependent. The most important example of the latter category is China. An increased taste for waterintensive food products by a growing population will exceed national production and turn China into a major player on the international food market, with increasing prices as a possible consequence.

In areas where water resources already appear to be overappropriated the scope for further blue water development appears to be limited. Many basins are approaching a withdrawal of $70 \%$ and some even go beyond $100 \%$. To safeguard aquatic and coastal ecosystems an environmental flow reserve of the order $30 \%$ of natural streamflow must remain in arid or semi-arid zone rivers. Already over-appropriated rivers can thus be restored (through reduction of present consumptive use) by freeing water part of today's agricultural and societal development. In basins still open for further blue water development environmental minimum levels will limit the degrees of freedom. Groundwater overdrafts, with falling water levels, also constitute a water quantity that sooner or later must be replaced as deepening of aquifers becomes economically unfeasible or water quality deteriorates. Reduced groundwater use implies a need for increased river flow withdrawals with further considerations regarding environmental flow.

Change in diet preferences towards more meat is a factor that strongly influences future consumptive water needs in agriculture. There is however a major difference in livestock/meat production: whether it is based on non-arable rangeland grazing and agriculture biomass residues, or it is based upon feed production that competes for water resources with food production. If feed is grown on lands that can produce vegetarian food for humans, the consumptive water use on these lands, irrigated or rainfed, to produce feed calories could instead be used for vegetarian food calories. Since efficiency in converting feed protein into meat protein is low compared to a vegetarian diet, meat from these areas accordingly implies a more water intensive diet.

According to FAO (2003) a quarter of the world's lands are used for grazing and extensive pasture, and provides $30 \%$ of total beef production and $23 \%$ of mutton. As rangelands are decreasing as a result of conversion into arable land, land degradation etc. the opportunity for increasing the number of animals in these systems is small. Present trends point at increasing intensive large-scale industrial live stock production with a substantial rise in cereal based feeds. Nierenberg (2003) estimates that $43 \%$ of today's world beef production comes from feedlots. Industrial enterprises globally already stand for $74 \%$ of poultry production, $68 \%$ of egg production and $40 \%$ of pig meat (FAO 2003). 


\subsection{Final remarks}

Future human development when seen in relation to consumptive water use can as shown in Fig. 6, be characterised as "Living with change, both in terms of efforts to intensify local production and increased water productivity on the field and of expansion to virgin lands". In the future further massive changes can be foreseen linked to human food security. Already today warning signals are evident showing that water use development has been unsustainable, with too far reaching river depletion and falling groundwater levels. This situation seriously complicates the necessary future expansion of food production and makes it a really challenging task. Reduced streamflow evidently also reduces the quantity available for dilution of pollution load, influencing water quality.

Many experts addressing local problems of socioeconomic development under increasing water scarcity suggest transition out of agriculture as a solution. However as seen globally food must be regarded as a human right. Hence maintained and expanded global food production can not be avoided. As pointed out by Postel (1999, p. 12) citing a speech to the U.S. Senate by the Harvard anthropologist T. Weiskel "There is no such thing as a post-agricultural society", adding "To act as if there were, is a recipe for societal collapse".

World future in terms of ability to feed humanity depends on many different factors and will be a choice of route limited by the development of coping capability. Agriculture is by no means a static activity, new modes will develop. Adjustment to an escalating water scarcity situation will take time. Transition time will be needed for agricultural modernisation and crop-per-drop improvement, even green houses. Food trade development is limited by purchasing power, infrastructure, trade barriers etc. Present food preferences point at more and more water intensive food consumption patterns, but if reversed, a less animal protein diet could be a tool towards reducing future consumptive water use demands.

In the long term a fully developed food trade system will open for global maximisation of comparative advantages according to regional differences in hydro-climate and hydrological preconditions.

Acknowledgements. Special thanks are due to A. Montanari and P. van der Zaag for valuable comments.

Edited by: H. H. G. Savenije

\section{References}

Ambio: Special Issue, Transboundary issues of shared waters, Ambio, 23, 1-2, 2004.

Asiancs Agro-Dev. International (Pvt) Ltd.: Tarbela Dam and related aspects of the Indus River Basin, Pakistan, AWCD case study prepared as an input to theWorld Commission on Dams, Cape Town, South Africa, 2000.
Bange, G. B.: The outlook for world grain and oilseed markets, presentation to Agricultural Outlook Conference, organised by China's National Grain and Information Centre, Beijing, 17-18 July 2004, 2004.

Berndes, G.: Bioenergy and water: The implications of large-scale bio energy production for water use and supply, Global Environmental Change, 12, 253-271, 2002

Brown, L.: World Creating Food Bubble Economy Based on Unsustainable Use of Water, Update 22: 13 March 2003-2, Earth Policy Institute, http://earth-policy.org, 2003a.

Brown, L.: Wakeup Call on the Food Front, Update 31: 16 December 2003-11, Earth Policy Institute, http://earth-policy.org, $2003 b$.

Brown, L.: Chinas shrinking grain harvest - How its growing grain imports will affect world prices, Update 36: 10 March 2004-5, Earth Policy Institute, http://earth-policy.org, 2004.

Calder, I. R.: Forests and water - Closing the gap between public and science perceptions, Proceedings Stockholm Water Symposium 2003, Water Science \& Technology, 2004.

Dyson, M., Bergkamp, G., and Scanlon, J. (Eds.): Flow, The essentials of environmental flows, IUCN, Gland, Switzerland, 2003.

Economist: IOU H2O, The Economist, 27 May 2000, 355, 8172, 31,2000

Economist: Pay up or dry up, The Economist, 26 May- 1 June 2001, 359, 8223, 33, 2001.

Falkenmark, M.: Landscape as life support provider, Water related limitations, In: Population - the complex reality, edited by: Graham-Smith, F., The Royal Society, London, 103-116, 1993.

Falkenmark, M.: Land-water linkages: a synopsis, Land and Water Integration and River Basin Management, FAO Land and Water Bulletin, Rome, 1, 15-16, 1995.

Falkenmark, M. and Rockström, J.: Balancing humans and nature, The new approach in ecohydrology, Earthscan, London, UK, 2004.

Foster, S. S. D. and Chilton, P. J.: Groundwater: the processes and global significance of aquifer degradation, Philosophical Transactions Royal Society London B, 358, 1935-1955, 2003.

Glantz, M. H.: Creeping environmental problems in the Aral Sea basin, in: Central Eurasian water crisis: Caspian, Aral and dead seas, edited by: Kobori, I. and Glantz, M. H., New York, USA, United Nations University Press, 1998.

Gleick, P. H.: The world's water - The biennial report on freshwater resources 2000-2001, Washington, D.C., USA, Island press, 2000.

Gordon, L., Dunlop, M., and Foran, B.: Land cover change and water vapour flows: learning from Australia, Philosophical Transactions Royal Society London B, 358, 1973-1984, 2003.

Gordon, L., Jönsson, B. F., Johannessen, Å., Steffen,W., Falkenmark, M., and Folke, C.: Largescale redistribution of global water vapour flows by deforestation and irrigation, in: Land use, freshwater flows and ecosystem services - In and era of global change, Gordon, L., 2003, Doctoral Thesis in Natural Resources Management, Department of Systems Ecology, Stockholm University, Sweden, 2004.

IFPRI: Data through personal communication with M. Rosegrant and from the book: World Water and Food to 2025, by Rosegrant, M. V., Cai, X., and Cline, S. A., International Food Policy Research Institute (IFPRI), Washington, D.C., 2002.

Kendy, E., Molden, D., Steenhuis, T. S., and Liu, C.: Policies drain 
the North China Plain - Agricultural policy and groundwater depletion in Luancheng County, 1949-2000, Research Report 71, International Water Management Institute, Colombo, Sri Lanka, 2003.

Kijne, J. W., Barker, R., and Molden, D.: Water Productivity in Agriculture - Limits and opportunities for improvement, CABI Publishing, Wallingford, UK, 2003.

L'vovich, M. I. and White, G. F.: Use and transformations of terrestrial water systems, in: The Earth as transformed by human action: Global and regional changes in the biosphere over the past 300 years, edited by: Turner II, B. L., Cambridge, UK, Cambridge University Press, 1990.

L'vovich, M. I.: World water resources and their future, English translation, edited by: Nace, R. N., (Russian edition 1974, edited by: Mysl', P. H., Moscow), Washington, D.C., USA, American Geophysical Union, 1979.

Lannerstad, M.: Consumptive Water Use Feeds the World and Makes Rivers Run Dry, MSc Thesis, Royal Institute of Technology (KTH), Stockholm, Sweden, 2002.

MDBC: Review of Cap Implementation 2001/2002 - Report of the independent audit group, March 2003, Murray Darling Basin Commission, Canberra, Australia, 2003.

MDBC: The Impacts of Water Regulation and Storage on the Basin's Rivers, Murray Darling Basin Commission, Canberra, Australia, retrieved 11 August 2004, http://www.mdbc.gov.au/education/encyclopedia/ water_regulation/water_regulation_impact.htm, 2003.

Meybeck, M.: Global analysis of river systems: from Earth system controls to Anthropocene syndromes, Philosophical Transactions Royal Society London B, 358, 1935-1955, 2003.

Moench, M., Burke, J., and Moench, Y.: Rethinking the approach to groundwater and food security, FAO Water Report 24, FAO, Rome, 2003.

Molden, D., Sakthivadivel, R., and Habib, Z.: Basin-level use and productivity of water: Examples from South Asia, Colombo, Sri Lanka: International water management institute, IWMI research report 49, 2001.

Oyama, M. D. and Nobre, C. A.: A new climate-vegetation equilibrium state for Tropical South America, Geophysical Research Letters, 30, 23, 2199-2203, 2003

Postel, S.: Pillar of sand: Can the irrigation miracle last? New York, USA, W. W. Norton \& Co., 1999.

Postel, S.: Where have all the rivers gone? Worldwatch, 8:9-19, World Watch Institute, Washington, D.C., U.S., 1995.

Ren, M. and Walker, H. J.: Environmental consequences of human activity on the Yellow River and its Delta, China. Physical Geography, 19, 5, 421-432, 1998.
Rockström, J.: Water for food and nature in drought-prone tropics: vapour shift in rain-fed agriculture, Philosophical Transactions Royal Society London B, 358, 1997-2009, 2003.

Rockström, J., Gordon, L., Folke, C., Falkenmark, M., and Engwall, M.: Linkages among water vapor flows, food production, and terrestrial ecosystems services, Conservation Ecology, 3, 2, 5, 1999.

Rosegrant, M. V., Cai, X., and Cline, S. A.: World Water and Food to 2025 International Food Policy Research Institute (IFPRI), Washington, D.C., 2002.

Savenije, H. H. G.: Does moisture feedback affect rainfall significantly?, Phys. Chem. Earth 20, 507-513, 1996.

Shah, T., Molden, D., Sakthivivadivel, R., and Seckler, D.: The global groundwater situation: Overview of opportunities and challenges, International Water Management Institute (IWMI), Colombo, Sri Lanka, 2000.

Shiklomanov, I. A.: Appraisal and assessment of world water resources, Water International, 25, 1, 11-32, 2000.

Smakthin, V., Revenga, C., and Döll, P.: Taking into Account Environmental Water Requirements in Global-scale Water Resources Assessments, Comprehensive Assessment Research Report 2, Colombo, Sri Lanka, Comprehensive Assessment Secretariat, 2004.

Taiz, T. and Zeiger, E.: Plant physiology, Benjamin/Cummings Publishing Company, Redwood City, California, U.S., 1991.

Tharme, R. E.: A global perspective on environmental flow assessment: Emerging trends in the development and application of environmental flow methodologies for rivers, Rivers research and applications, 19, 397-441, 2003.

UN: World Population Prospects - The 2002 Revision, United Nations, 2003.

USDA: World Agricultural Supply and Demand Estimates, WASDE-412, 12 July 2004, U.S. Department of Agriculture, Office of the chief economist, retrieved 16 July 2004, sasmehttp: //www.usda.gov/oce/waob/wasde/latest.pdf, 2004.

Van der Zaag, P. and Carmo Vaz, Á.: Sharing the Incomati waters, cooperation and competition in the balance, Water Policy, 5, 349-368, 2003.

Yang, H., Reichert, P., Abbaspour, K. C., and Zehnder, A. J. B.: A water resources threshold and its implications for food security, in: Virtual water trade, Proceedings of the international expert meeting on vitural water trade, Delft, The Netherlands, edited by: Hoekstra, A. Y., Value of Water, Research Report Series No. $12,2003$. 